\title{
PEMBELAJARAN BAHASA INDONESIA YANG MENCERDASKAN DAN TANGGUNG JAWAB MENGHASILKAN GENERASI LITERAT
}

\author{
Oleh :
}

Prof. Dr. Sarwiji Suwandi, M. Pd.

Universitas Sebelas Maret

\begin{abstract}
ABSTRAK
\section{Pendahuluan}

Melalui surat undangan untuk menjadi pembicara dalam rangka Seminar Nasional di Universitas Kuningan saya diberi tahu bahwa seminar ini mengangkat tema "Berliterasi dengan Bahasa dan Sastra." Sekurang-kurangnya ada dua kata kunci dalam tema tersebut, yaitu "berliterasi" dan "bahasa dan sastra".Selain itu, ada satu kata antara kedua kata kunci tersebut, yakni kata dengan yang berarti 'menggunakan suatu alat atau media'. Tatakala dibaca secara lengkap, tema itu kurang lebih dapat dimaknai berliterasi dengan menggunakan bahasa dan sastra (baca: bahasa dan sastra Indonesia) sebagai sarananya.

Kata literasi itu sendiri sering diartikan sebagai sebuah kemampuan membaca dan menulis atau sering digunakan untuk mengacu konsep melek aksara atau keberaksaraan. Seturut dengan itu, berliterasi mengacu pada konsep

aktivitas membaca atau menulis atau berkemampuan membaca dan menulis.Jika demikian pemaknaannya, tampaknya diskusi tentang tema tersebut momentumnyatelah lewat atau bisa dianggap selesai. Bukankah kita samasama tahu bahwa bahasa memiliki fungsi sebagai wadah dan sekaligus pengembang kebudayaan, bahasa sebagai sarana memahami hasil olah pikir dan rasa manusia yang tertuang dalam teks-teks dan sekaligus sarana mengekspresikan dan mendesiminasikan olah pikir dan rasa orang atau keompok orang kepada orang lain melalui teks-teks juga.

Pertanyaannya kemudian adalah apakah diskursus berliterasi dengan bahasa dan sastra benar-benar sudah memadai dan memberikan solusi atas permalasalahan yang ada. Tentu belum dan bahkan tidak pernah selesai! Persoalannya bukan semata-mata bahasa sebagai media literasi.Bahkan, jika literasi dibatasi pada makna melek aksara atau
\end{abstract}


FON ; Jurnal Pendidikan Bahasa dan Sastra Indonesia

Volume 13 Nomor 2 Tahun 2018

kebraksaraan pun masih banyak masalah tersisa.Memang, Indonesia tercatat sebagai salah satu negara yang berhasil mengurangiangka buta huruf. Data UNDP tahun 2014 mencatat bahwa tingkat kemelekaksaraan masyarakat Indonesia mencapai 92,8\% untuk kelompok dewasa, dan 98,8\%untuk kategori remaja. Capaian ini sebenarnya menunjukkan bahwa Indonesiatelah melewati tahapan krisis literasi dalam pengertian kemelekaksaraan.

Meskipundemikian, tantangan yang saat ini dihadapi adalah rendahnya minat baca.Selain ketersediaan buku di seluruh Indonesia belum memadai, pemerintah jugamenghadapi rendahnya motivasi membaca di kalangan peserta didik.Hal inimemprihatinkan karena di era teknologi informasi, peserta didik dituntut untukmemiliki kemampuan membaca dalam pengertian memahami teks secara analitis,kritis, dan reflektif.Sementara itu, masyarakat global dituntut untuk dapat mengadaptasi kemajuan teknologi dan keterbaruan. Untuk itu, perlu disadari pentingnya literasi informasi (information literacy), yaitu kemampuan untukmencari, memahami, mengevaluasi secara kritis, dan mengelola informasi menjadipengetahuan yang bermanfaat untuk pengembangan kehidupan pribadi dan sosialnya.

Literasi dan berliterasi merupakan suatu soalan yang kompleks.Namun kompleks tidak selalu berarti rumit.Kerumitan sering terjadi karena tidak adanya kesungguhan untuk berbuat.Literasi dan berliterasi memiliki spektrum kajian yang luas dan berkaitan dengan banyak variabel, baik kajian dalam perspektif teoretis maupun praksis.Literasi itu sendiri ada beraneka ragam. Oleh karenanya, kita pun perlu menyatakan secara eksplisit literasi manakah yang kita makudkan.

Program literasi mencakup upaya mengembangkan potensi kemanusiaan yang mencakup kecerdasan intelektual, emosional, sosial, spiritual, bahasa, estetika, dengan daya adaptasi terhadap perkembangan arus teknologi dan informasi.Literasi berkaitan dengan upaya pembudayaan yang mengjangkau banyak sasaran, dari anak-anak, siswa, mahasiswa, generasi muda, orang dewasa, pendidik, birokrat, pejabat, dan sebagainya.Literasi juga berkaitan dengan para pihak yang terlibat dengan upaya pembinaan dan pembudayaan, yakni keluarga, pendidik profesional, pakar, pemerintah, dan lain-lain.Mereka bukan saja dituntut mentransfer pengetahuan, 
tapi yang lebih utama adalah membina, memberi dorongan, memberi semangat, memberi contoh praktik berliterasi, dan bahkan mampu menginspirasi. Berliterasi juga bertalian dengan erat ketersediaan kebijakan dan regulasi, penyediaan buku dan sarana prasarana lain yang memadai, mentor yang dedikatif, dan iklim yang kondusif.

Berkenaan dengan kompleksitas literasi, sangat masuk akal jika literasi menarik banyak orang untuk dikajidalami.Kata literasi dalam dekade ini tampaknya merupakan salah satu kata yang cukup seksi, kata yang mampu menyedot perhatian banyak kalangan. Banjir kata literasi bukan hanya terjadi di forum-forum ilmiah, diskusi di kampus dan sekolah, talk show di media elektonik (radio atau televisi), dicanangkan sebagai gerakan, tulisan opini di media cetak; tetapi juga dalam kehidupan sehari-hari melalui komunikasi persemukaan (Suwandi, 2016). Literasi menjadi kata yang banyak diucapkan, bukan saja oleh orang-orang yang bergulat di dunia pendidikan (seperti dosen, guru, kepala sekolah, pengawas, dekan, rektor, dan menteri), pakar atau yang sedang belajar untuk menjadi pakar, pengamat pendidikan atau yang sedang belajar menjadi pengamat, peneliti, birokrat pendidikan; tetapi tak jarang pula oleh awam. Bahkan, rasanya belum lengkap kalau pejabat belum beretorika tentang literasi, sebagaimana mereka belum lengkap dalam pidato tatkala belum mengunakan kata wacana.Banjir kata literasi terjadi baik dalam dunia nyata maupun dunia maya.

Berikutnya saya akan lebih berfokus pada ikhtiar mengembangkan budaya literasi untuk menghasilkan generasi (baca: peserta didik) yang literat, generasi yang bukan saja memiliki pemahaman atas apa yang dibaca, tapi juga melakukan sesuatu berdasarkan pemahamannya atas isi bacaan tersebut. Generasi literat adalah generasi yang cerdas, mumpuni, berkarakter, dan berdaya saing.Karena generasi literat saya batasi pada peserta didik, ketersediaan bahan ajar-khususnya teks-danperan guru atau pendidik akan menjadi sorotan. Akhirnya, saya akan memberikan beberapa masukan guna mewujudkan generasi literat tersebut.

\section{Generasi kini: Haruskah "dirisaukan?"}

Kita menyaksikan kecenderungan menguatnya budaya materialisme yang lebih mengedepankan kebendaan serta budaya klobotik yang lebih memamerkan 
pada penampilan.Hal demikian juga facebook, instagram, twitter dan lainnya. tampak pada anak-anak didik dan generasi Dalam laporan ini juga terungkap, pada muda kita. Mereka rela membelanjakan Januari 2018, dari total masyarakat uang yang dimiliki dalam jumlah banyak Indonesia berjumlah 265,4, penetrasi untuk sebuah penampilan (pakaian, penggunaan internet mencapai 132,7 juta sepatu, HP, hal-hal lain yang bersifat pengguna.Jika membandingkan antara asesoris), tapi mereka sangat berhitung jumlah pengguna internet dengan tatkala harus mengeluarkan uang untuk pengguna media sosial, sekitar 97,9 kebutuhan membeli buku atau bahan pengguna internet di Indonesia sudah bacaan lain. Banyak waktu yang mereka menggunakan media sosial. Sementara itu, gunakan untuk "kumpul-kumpul" yang jika dibandingkan dengan total penduduk lebih pada persendagurauan daripada Indonesia, sekitar 48 persen penduduk berdiskusi mengenai isu-isu aktual untuk kepentingan studinya, nonton (film, video, televisi), banyak waktu yang mereka gunakan untuk mendengarkan musik daripada belajar untuk kepentingan sekolahnya.Generasi muda kita banyak terbius pada mode. Fenome ini tidak sulit ditemukan baik di kota maupun di desa. Hedonisme dan budaya pop sudah begitu masuk ke sendi-sendi kehidupan generasi muda, atau bahkan kita semua.

Indonesia telah mencicipi media sosial. Mengenai jumlah waktu yang dihabiskan oleh masyarakat Indonesia, rata-rata setiap harinya satu orang mengakses sekira 8 jam 51 menit. Sementara itu, lama waktu untuk menggunakan media sosial dari berbagai perangkat mencapai 3 jam 23 menit per hari (https://wearesocial.com/uk/blog/2018/01/ global-digital-report-2018).

Rerata penggunaan media sosial 3 Berkenaan dengan kegiatan jam 23 menit tentu bukanlah durasi waktu bermedia sosial, dalam sebuah penelitian yang singkat. Mereka tentu membaca dan terbaru yang dilakukan oleh We Are menulis. Jika demikian, pertanyaan-yang Social dan Hootsuite, terungkap bahwa tentu suatu ironi-apakah masih perlu masyarakat Indonesia sangat gemar dan aktif mengunjungi media sosial. Tercatat, setidaknya kini ada sekitar 130 juta masyarakat Indonesia yang aktif di berbagai media sosial, mulai dari ditingkatkan atau dikembangkan daya literasi mereka?Bukankan mereka sudah begitu "rajin" membaca dan menulis?Barangkali kita bisa bersepakat bahwa mereka pada umumnya bukanlah 
FON ; Jurnal Pendidikan Bahasa dan Sastra Indonesia

Volume 13 Nomor 2 Tahun 2018

pembaca dan penulis yang kita Terjadinya penurunan kompetensi harapkan.Teks-teks yang mereka dan tulis tekstual—baca maupun tulis_-tentu bukanlah teks yang berkategori disebabkan oleh banyak faktor.Salah satu bermutu.Mereka sering membaca teks- faktor penting sebagaimana telah teks yang belum teruji kesahihannya, dikemukakan di atas dan juga dinyatakan bahkan terkadang berkategori hoax.Teks- Damshäuser (2016) adalah pemakaian teks yang mereka hasilkan pun sering sebuah alat bernama smart-phone.Alat itu berupa teks-teks reaktif yang kurang sungguh ajaib. Sebuah komputer mini bermutu.Mereka banyak menyantap dan yang terkoneksi dengan world wide web memproduksi teks-teks banal dan bahkan sehingga melaluinya pengguna punya sangat banal, yang sangat perlu akses ke hampir semua bidang direnungkan kemanfaatannya.

Terus terang saya harus pengetahuan atau ilmu, kepada jutaan teks bermutu, termasuk karya para filsuf dan menyatakan bahwa sebagai pendidik, saya cukup risau dengan keadaan di pujangga agung, paling sedikit dalam atas.Sebagai seorang pendidik, saya cemas tatkala menyaksikan masih banyak siswa dan mahasiswa kurang memiliki kesanggupan menyusun teks yang memadai, baik dari segi isi, logika, gramatika, pilihan kata, dan bahkan persoalan penggunaan tanda baca.Kurang bermutunya isi teks dengan mudah dapat kita ketahui penyebabnya.Mereka pada umumnya kurang dalam aktivitas membaca atau aktivitas membaca sudah mereka lakukan, namun kurang dalam hal kemampuan membaca komprehensif, intensif, dan kritis.Sementara itu, kekurangan pada aspek logika dan bahasa lebih disebabkan kurangnya mereka berlatih menulis.

bahasa aslinya atau terjemahan ke bahasa Inggris. Sebuah perpustakaan mahabesar tertemukan "di dalam" alat mungil itu yang dapat kita bawa di saku kita sehingga kapan dan di mana pun dapat kita gunakan, asal ada koneksi ke internet. Mestinya, alat itu memberi sumbangan besar dalam upaya mencerdaskan dan memperkaya tiap manusia, tiap tamadun. Alat itu memungkinkan, misalnya, membaca puisi Chairil Anwar, Taufiq Ismail, K.H. Mustofa Bisri, Acep Zamzam Noor, dan sebainya sambil mendengarkan musik Mozart ataupun gamelan Jawa.

Sungguh sebuah ironi, alat ajaib itu—sang perpustakaan ilmu dan pengetahuan global-hampir sama sekali tidak menyumbang pada peningkatan akhlak 
FON ; Jurnal Pendidikan Bahasa dan Sastra Indonesia

Volume 13 Nomor 2 Tahun 2018

dan budi, melainkan menjadi penyebab sebuah perubahan fundamental dalam kehidupan manusia yang justru diiringi dampak yang sangat merugikan. Berbagai penelitian terhadap penggunaan dan para pengguna smart-phone menunjukkan hasil yang mencemaskan. Alat yang mesti menjadi hamba, justru menjadi tuan yang memperbudak. Ia sanggup menjadi tuan dan peneror karena ia bagaikan sebuah narkoba, bagaikan heroin. Pengguna atau "penikmat" tak sanggup lagi melepaskan diri darinya, malah menyatu dengannya. Maklum, ia bisa dibawa ke mana-mana sehingga terdapat semacam simbiosis antara alat dan pengguna. Bila terpisah dari alat, si pengguna bahkan menderita, menderita seperti orang yang kecanduan narkoba.

Sunguhpun masih perlu pembuktian secara empiris, teks yang dibaca dan ditulis oleh pengguna smartphone adalah teks-teks singkat dan banal. Menurut Damshäuser (2016), kesingkatan dan kebanalan demikian justru menjauhkan manusia dari teks panjang dan bermutu. Meskipun harus ditegaskan bahwa teks bermutu tidak selalu berupa teks panjang; misalnya puisi atau sajak.Karya seni bahasawi inimeminjam istilah Damshäusermerupakan teks yang disusun secara artistik sehingga lahir sesuai yang tidak sekadar mengadung unsur isi semantis, tetapi juga memesonakan melalui bentuknya. Bentuknya diwarnai musikalitas, dan dihasilkan dengan menggunakan alat-alat puitis tertentu, yaitu irama/metrum dan bunyi, terutama rima.

\section{Literasi}

Sebagaimana telah dijelaskan bahwa dalam arti sempit, literasi sering diartikan sebagai sebuah kemampuan membaca dan menulis atau mengacu pada keberaksaraan.Namun, sekarang ini literasi memiliki arti luas sehingga keberaksaraan bukan lagi bermakna tunggal melainkan mengandung makna jamak, atau beragam arti (multi literacies). Definisi baru dari literasi menunjukkan paradigma baru dalam upaya memaknai literasi dan proses pembelajarannya.

Literasi dalam arti luas sejatinya sudah cukup lama menjadi acuan UNESCO. Bisa kita baca Literacy for Life, laporan UNESCO tahun 2006 tentang literasi dunia.Dalam laporan itu dinyatakan bahwa literasi adalah hak dasar manusia sebagai bagian esensial dari hak pendidikan.Terpenuhinya hak literasi memungkinkan kita mengakses sains, pengetahuan teknologi, aturan hukum, dan 
FON ; Jurnal Pendidikan Bahasa dan Sastra Indonesia

Volume 13 Nomor 2 Tahun 2018

mampu memanfaatkan kekayaan budaya, meliputi pendidikan, komunikasi, dan daya guna media (Wardi, 2013). administrasi, hiburan, militer, dan Dengan demikian literasi menjadi poros sebagainya.Literasi ini mencirikan tingkat upaya peningkatan kualitas hidup manusia kualitas bangsa di bidang-bidang dan karenanya merupakan sumbu pusaran tersebut.Ketiga, dimensi keterampilan, pendidikan.

Ada beraneka macam yang meliputi membaca, menulis, menghitung, dan berbicara.Literasi ini keberaksaraan atau literasi, misalnya bersifat individu yang dapat dilihat dari literasi media (media literacy), literasi tampak dan semaraknya kegiatan digital (digital letaracy), literasi membaca, menulis, menghitung, dan informasi (information literacy), literasi berbicara. Dalam tradisi orang barat, ada computer (computer letery), literasi tiga keterampilan dasar yang lazim emosional (emotionalliteracy atau diutamakan, yakni: reading, writing, dan emotional intelligence), literasi ekologis arithmetic. Keempat, dimensi fungsi, (ecological letaracy), dan sebagainya. yakni fungsi literasi untuk memecahkan Hakikat berliterasi secara kritis dalam persoalan, memenuhi persyaratan dalam masyarakat yang demokratis dapat upaya mendapatkan pekerjaan, mencapai diringkas dalam lima verba, yakni tujuan, mengembangkan pengetahuan, dan memahami, melibati, menggunakan, meningkatkan kapasitas pribadi dan menganalisis, dan mentransformasi potensi diri.Kelima, dimensi media (teks, beraneka ragam informasi (utamanya cetak, visual, digital).Seiring dan sejalan teks).

Dalam perkembangannya literasi dengan perkembangan teknologi yang sangat pesat, begitu juga teknologi dalam terus berevolusi dan karenanya rujukannya makin meluas dan media literasi.Keenam, dimensi jumlah (kuantitas). Kemampuan yang berkaitan kompleks.Literasi memiliki tujuh dimensi dengan jumlah (kuantitas) ini tumbuh dan yang berurusan dengan penggunaan berkembang karena proses pendidikan bahasa.Pertama, dimensi geografis, yang meliputi daerah lokal, nasional, regional, dan internasional.Literasi ini bergantung pada tingkat pendidikan dan jejaring sosial.Kedua, dimensi bidang, yang yang berkualitas tinggi. Karena seperti halnya kemampuan berkomunikasi pada umumnya, kemampuan literasi yang berkaitan dengan jumlah, juga bersifat relatif.Ketujuh, dimensi bahasa (etnis, 
lokal, internasional). Proses literasi yang terjadi bisa singular maupun plural. Hal inilah yang menjadikan literasi bisa merupakan proses monolingual, bilingual, dan multilingual. Ketika seseorang mampu menulis dan berlitersi dengan bahasa daerah, bahasa Indonesia dan bahasa Inggris, ia disebut seseorang yang berkemampuan multilingual.

Selain jenis literasi yang telah disebutkan di atas, dikenal pula literasi linguistis, yakni aspek-aspek kompetensi literasi yang dinyatakan dalam bahasa sesuai dengan aspek-aspek pengetahuan linguistik yang dipengaruhi oleh kompetensi literasi dan perkembangan literasi linguistis sebagai bagian dari kemampuan kognitif mereka. Pandangan tentang literasi linguistik terdiri atas penentuan fitur (kontrol atas variasi linguistik baik dari perspektif pengguna maupun konteks (modalitas, genre, dan laras); proses bersamaan (metabahasa dan perannya dalam perkembangan bahasa); keadaan (keakraban dengan tulisan dan bahasa tulis dari dua aspek, yakni bahasa tulis sebagai wacana (pengakuan bahwa bahasa yang digunakan untuk menulis pada dasarnya berbeda dengan yang digunakan untuk berbicara) dan bahasa tulis sebagai sistem notasi (persepsi dan perkembangan sistem yang digunakan dalam modalitas tertulis. Literasi linguistis dipandang sebagai konstituen pengetahuan bahasa yang dicirikan oleh ketersediaan berbagai sumber daya linguistik dan kemampuan untuk secara sadar mengakses pengetahuan linguistik yang dimilikinya dan memandang bahasa dari berbagai perspektif (Ravid dan Tolchinsky, 2002: 417).

Sikap terhadap bahasa sebagai komponen penting dari literasi linguistis. Fitur leksikal, sintaksis, dan wacana dari konstruksi teks dipengaruhi oleh media ekspresi yang diplih dan digunakan.Wacana lisan sering direalisasikan dengan kalimat pendek, tidak lengkap, dan kurang gramatikal. Wacana tulis sering direalisasikan dalam uraian yang lebih lengkap, penuh informasi penjelas,dan lebih gramatikal. Wacana lisan sering menggunakan bentuk-bentuk informal, sedangkan wacana tulis banyak menggunakan bentuk-bentuk baku.

\section{Pengembangan Literasi}

Generasi muda—khususnya pelajar dan mahasiswa-akanmemikul tanggung jawab dalam memajukan peradaban dan menciptakan keunggulan bangsa Indonesia(Suwandi, 2015a). Dalam konstelasi percaturan global yang 
FON ; Jurnal Pendidikan Bahasa dan Sastra Indonesia

Volume 13 Nomor 2 Tahun 2018

makin kompetitif, generasi muda memiliki tanggung jawab yang tidak ringan dalam meningkatkan posisi tawar bangsa Indonesia`di mata dunia internasaional. Peran mereka sebagai subjek sejarah, aktor kritis, kreator, dan inovator yang menentukan wajah masa depan bangsa Indonesia harus kita siapkan sejak dini dan dikembangkan secara berkelanjutan. Untuk pengembangan budaya literasi bagi mereka merupakan keniscayaan.

Pengembangan budaya literasi sesungguhnya telah dilakukan sejak lama, antara lain melalui "gerakan ayo membaca" yang dicanangkan pemerintah. Pengembangan budaya literasi untuk siswa pun telah menjadi perhatian pemerintah. Dalam Permendiknas No. 22 Th. 2006 tentang Standar Isi ditegaskan bahwa pada akhir pendidikan di SD/MI, peserta didik telah membaca sekurangkurangnya sembilan buku sastra dan nonsastra; pada akhir pendidikan di SMP/MTs, peserta didik telah membaca sekurang-kurangnya 15 buku sastra dan nonsastra; dan pada akhir pendidikan di SMA/MA, peserta didik telah membaca sekurang-kurangnya 15 buku sastra dan nonsastra.Namun demikian, hampir 10 tahun KTSP diimplementasikan, tampaknya target tersebut tidak tercapai. Alih-alih menugasi siswa membaca buku sain dan sastra, dalam pembelajaran bahasa Indonesia di sekolah pun guru sering tidak menggunakan buku ajar dan menggantikannya dengan LKS.

Mata pelajaran bahasa Indonesia dalam Kurikulum 2013 pun memberi perhatian pada pengembangan budaya literasi melalui pembelajaran berbasis teks (2014). Melalui pembelajaran berbasis teks, kompetensi tekstual siswa akan meningkat. Tentu dengan asumsi guru tidak terjebak untuk menjelaskan berbagai pengertian teks dengan segenap cirinya dalam pembelajaran bahasa Indonesia dan kurang memberikan pelatihan memproduksi teks. Ini merupakan hal yang paling rentan terjadi dalam tang teks, baik pada aspek reseptif maupun produktif. Kemampuan guru dalam menghasilkan teks baik secara lisan dan tulis masih kurang. Demikian pula, kemampuan membaca mereka masih belum baik yang antara lain karena belum bertumbuhnya minat dan budaya baca.

Unsur penting dalam pembelajaran berbasis teks adalah membangun konteks. Guru perlu menyiapkan mental siswa dalam mempelajari teks tertentu. Hal ini harus disadari oleh guru karena tidak ada teks yang nirkonteks.Dalam pembelajaran tentu siswa tidak berangkat dari sebuah kekosongan. Guru tidak boleh 
FON ; Jurnal Pendidikan Bahasa dan Sastra Indonesia

Volume 13 Nomor 2 Tahun 2018

berpandangan bahwa siswa tidak bisa dicapai. "Reading is the heart of mengetahui apapun tentang sesuatu topik. education". Membaca dan selanjutnya

Sungguhpun Kurikulum 2013 memroduksi tulisan adalah fardu ain bagi sangat menekankan kompetensi anak guru/dosen(Suwandi, 2015b).

dalam membaca dan menulis melalui

Bagi dosen, budaya literasi pembelajaran berbasis teks, kurikulum ini berkaitan erat dengan budaya tidak mematok target minimal buku yang meneliti.Perguruan tinggi sebagai lembaga harus dibaca siswa.Dilihat dari sisi ini, ilmiah sudah sepantasnya memiliki tampak kegamangan Kurikulum dinamika yang tinggi dalam 2013.Secara berpikir sederhana pun tentu penelitian.Akan tetapi, kegiatan penelitian dapat dipahami bahwa jika para siswa di perguruan tinggi masih terbatas dituntut mampu memproduksi tulisan, pula.Produktivitas penelitian dan menulis maka tentu mereka harus banyak artikel yang dipublikasi di jurnal ilmiah membaca. Melalui aktivitas banyak belum sebanding dengan jumlah membaca para siswa akan mendapat perguruan tinggi dan dosen yang ada di banyak inspirasi, memiliki gagasan dan Indonesia. Faktor paling klasik yang wawasan yang kaya, dan sekaligus sering mengemuka adalah terbatasnya memperoleh banyak model tulisan yang dana dan kompetensi tenaga penelitian. baik.

Gurudandosen memikul tanggung Alasan tersebut sebenarnya tidak terlalu tepat kerana pemerintah telah jawab penting untuk mengatasi masih mengalokasikan dana dalam jumlah cukup rendahnya literasi siswa. Upaya tersebut besar melalui berbagai skim penelitian dapat berhasil manakala guru/dosen (unggulan perguruan tingi, tim sendiri telah memiliki budaya literasi. pascasarjana, fundamental, disertasi Budaya literasi terebut bukan saja untuk doktor, dosen pemula, unggulan strategis siswa, tapi juga sangat dibutuhkan bagi nasional, kerja sama luar negeri dan pengembangan profesionalisme publikasi internasional, kompetensi, guru/dosen. Semua proses belajar strategis nasional, dan sebagaiya) dan didasarkan pada kemampuan membaca. sering tidak semua dana yang disediakan Dengan aktivitas membaca yang bisa terserap.

membudaya pada peserta didik dan Tanggung jawab pendidik dalam pendidik, keberhasilan pendidikan akan mengembangkan budaya literasi peserta 
FON ; Jurnal Pendidikan Bahasa dan Sastra Indonesia

Volume 13 Nomor 2 Tahun 2018

didik dilakukan dalam konteks mengefektifkan pembelajaran bahasa pembelajaran maupun di luar Indonesia. Pendidikmemiliki banyak pembelajaran.Pendidik harus mampu kemungkinan masuk ke ruang kelasnya menanamkan cara berpikir positif pada dengan dilengkapi pengetahuan, baik diri siswa. Siswa terus-menerus didorong merupakan hasil penelitian atau riset yang untuk memiliki pikiran positif untuk telah dilakukannya maupun riset yang mengembangkan drinya.Para siswa dilakukan ahli pendidikan. Setiap tahun hendaknya menyadari bahwa belajar ahli-ahli pendidikan dan juga ahli bukan saja terjadi di ruang kelas atau di psikologi pendidikan menemukan dan sekolah.Belajar bukan saja saat bertemu memperbaiki prinsip-prinsip pengjaran dengan guru di sekolah. Belajar-yang dan pembelajaran yang bermanfaat bagi antara lain melalui aktivitas membaca- pendidik yang berpraktik. Namun dapat dilakukan di mana saja dan kapan demikian, sebagaimana diingatkan oleh saja. Siswa dapat berinteraksi dengan Slavin (2008: 18), penting bagi pendidik berbagai sumber belajar.Pikiran positif menjadi konsumen riset yang cerdas, yang untuk menjadi insan yang selalu punya tidak serta-merta memungut setiap temuan keinginan memperkaya pengetahuan dan atau setiap pernyataan pakar sebagai keterampilan harus digelorakan pada diri siswa.Tindakan-tindakan positif pendidik untuk menyemaikembangkah pikiran dan tindakan positif bukanlah sebuah pilihan, tapi merupakan sebuah kebutuhan.Sebagaimana ditegaskan oleh Orick (2002: 86) bahwa tindakan positifadalah langkah yang palingpentingyang bisa kita ambilsebagai individu danmasyarakatuntuk mempengaruhiperubahan nyata.

Pendidik-guru dan dosen bahasa Indonesia-yangmerupakan pemikir intensional dan kritis hendaknya dapat mengambil pilihan yang tepat dalam kebenaran.

Kompetensi akademik peserta didik perlu secara terus-menerus diasah dan dikembangkan. Kunci kompetensi akademikuntuk menghasilkan pengetahuan bagi masyarakat informasi saat ini, menurut Delgadova (2015) — adalahliterasi membaca.

Dalam pembelajaran bahasa Indonesia, guru dituntut memberikan pengertian kepada peserta didik, dan bukan sekadar memindahankan sejumlah rumusan kepada siswa untuk disimpan yang kemudian akan dikeluarkan dalam bentuk yang sama jika diperlukan. 
Peserta didik haruslah dilihat sebagai Murid tidak dilihat dan ditempatkan pribadi aktif yang dapat membuat pilihan- sebagai objek yang harus diajar dan pilihan atas tanggung jawab pribadi menerima.Demikian pula sebaliknya guru mengenai pendidikannya sendiri. Mereka tidak berfungsi sebagai pengajar. Guru perlu didorong dan difasilitasi untuk dan murid adalah sama-sama belajar dari berkembang menjadi suatu pribadi yang masalah yang dihadapi. Guru lahir dari dirinya sendiri.

danmuridadalah subjek dalam Pembelajaran yang dilaksanakan memecahkan permasalahan. guru bahasa Indonesia hendaknya Guru bertindak dan berfungsi sebagai mampu-membangun kesadaran kritis koordinator dan fasilitator transitif, yang ditandai dengan kedalaman yang memperlancar percakapan dialogis. menafsirkan berbagai Ia adalah teman dalam memecahkan permasalahan, membangun rasa percaya permasalahan. Sementara itu, peserta diri dalam diskusi, serta membangun didik adalah partisipan aktif dalam kemampuan untuk mampu menerima dan menolak. Pembelajaran-sebagai proses interaksi edukatif antara pendidik dan peserta didik dengan sumber belajathendaknya mempu mewujudkan kemampuan merefleksi.

Sudah barang pasti pembelajaran tidak dimakdsudkan agar peserta didik atau murid langsung mencapai tingkatan kesadaran tertinggi. Belajar adalah proses bergerak dari kesadaran peserta didik pada masa kini ke tingkatan kesadaran yang di atasnya. Dalam proses belajar yang demikian pertentanganpendidik-peserta didik_perbedaan guru sebagai dialog tersebut.

Pencip suasana pembelajaran yang dialogis serta pembelajaran yang mampu mengembangkan penalaran dan kreativitasmenuntut guru perlu secara terus-menerus dan berkelanjutan mengembangkan minat baca siswa dan tentu juga dirinya. Gurudituntut menyediakan buku-buku atau bahan bacaan yang bermutu, baik buku-buku sains maupun sastra. Pada era digital ini seperti sekarang ini, guru dapat mengakses bahan bacaan berkualitas dalam jumlah yang begitu banyak dan menyediakannya bagi siswa.Siswa-siswa sumber segala pengetahuan dan murid pun difasilitasi untuk dapat mengaksesnya sebagai orang yang tidak serba kurang sendiri.Yang lebih penting lagi guru atau tidak tahu-tidak akan terjadi. kahadiran guru sebagai mentor bagi siswa 
FON ; Jurnal Pendidikan Bahasa dan Sastra Indonesia

Volume 13 Nomor 2 Tahun 2018

dalam aktivitas membaca, menulis, dan tidak hanya menjadi guru biasa (just menghasilkan karya-karya kreatif lainnya. ordinary teacher), melainkan a

Guru dituntut memiliki hasrat greatteacher, bahkan menjadi a legend.

menggelora untuk melihat para siswa Kita tentu tidak berharap praktik bertumbuh, bermetamorfosis, dan pembelajaran bahasaIndonesia menyempurna menjadi insan-insan yang sebagaimana secara satire diungkapkan mampu memberdaya dan Taufiq Ismail melalui puisi di bawah ini. mengaktualisasikan dirinya. Guru dituntut

\section{PELAJARAN TATABAHASA DAN MENGARANG}

\section{Taufiq Ismail}

"Murid-murid, pada hari Senin ini

Marilah kita belajar tatabahasa

Dan juga sekaligus berlatih mengarang

Bukalah buku pelajaran kalian

Halaman enam puluh sembilan

"Ini ada kalimat menarik hati, berbunyi

'Mengeritik itu boleh, asal membangun'

Nah anak-anak, renungkanlah makna ungkapan itu

Kemudian buat kalimat baru dengan kata-katamu sendiri.”

Demikianlah kelas itu sepuluh menit dimasuki sunyi

Murid-murid itu termenung sendiri-sendiri

Ada yang memutar-mutar pensil dan bolpoin

Ada yang meletakkan ibu jari di dahi

Ada yang salah tingkah, duduk gelisah

Memikirkan sejumlah kata yang bisa serasi

Menjawab pertanyaan Pak Guru ini

“Ayo siapa yang sudah siap?" 
FON ; Jurnal Pendidikan Bahasa dan Sastra Indonesia

Volume 13 Nomor 2 Tahun 2018

Maka tak ada seorang mengacungkan tangan

Kalau tidak menunduk sembunyi dari incaran guru

Murid-murid itu saling berpandangan saja

Akhirnya ada seorang disuruh maju ke depan

Dan dia pun memberi jawaban

"Mengeritik itu boleh, asal membangun

Membangun itu boleh, asal mengeritik

Mengeritik itu tidak boleh, asal tidak membangun

Membangun itu tidak asal, mengeritik itu boleh tidak

Membangun mengeritik itu boleh asal

Mengeritik membangun itu asal boleh

Mengeritik itu membangun

Membangun itu mengeritik

Asal boleh mengeritik, boleh itu asal

Asal boleh membangun, asal itu boleh

Asal boleh itu mengeritik boleh asal

Itu boleh asal membangun asal boleh

Boleh itu asal

Asal itu boleh

Boleh boleh

Asal asal

Itu itu

Itu."

"Nah anak-anak, itulah karya temanmu

Sudah kalian dengarkan 'kan

Apa komentar kamu tentang karyanya tadi?"

Kelas itu tiga menit dimasuki sunyi

Tak seorang mengangkat tangan 
FON ; Jurnal Pendidikan Bahasa dan Sastra Indonesia

Volume 13 Nomor 2 Tahun 2018

Kalau tidak menunduk di muka guru

Murid-murid itu cuma berpandang-pandangan

Tapi tiba-tiba mereka bersama menyanyi:

"Mengeritik itu membangun boleh asal

Membangun itu mengeritik asal boleh

Bangun bangun membangun kritik mengeritik

Mengeritik membangun asal mengeritik

"Dang ding dung ding dang ding dung

Ding dang ding dung

Dang ding dung ding dang ding dang

Ding dang ding dung."

"Anak-anak, bapak bilang tadi

Mengarang itu harus dengan kata-kata sendiri

Tapi tadi tidak ada kosa kata lain sama sekali

Kalian cuma mengulang bolak-balik yang itu-itu juga

Itu kelemahan kalian yang pertama

Dan kelemahan kalian yang kedua

Kalian anemi referensi dan melarat bahan perbandingan

Itu karena malas baca buku apalagi karya sastra."

"Wahai Pak Guru, jangan kami disalahkan apalagi dicerca

Bila kami tak mampu mengembangkan kosa kata

Selama ini kami 'kan diajar menghafal dan menghafal saja

Mana ada dididik mengembangkan logika

Mana ada diajar berargumentasi dengan pendapat berbeda

Dan mengenai masalah membaca buku dan karya sastra

Pak Guru sudah tahu lama sekali

Mata kami rabun novel, rabun cerpen, rabun drama dan rabun puisi 
FON ; Jurnal Pendidikan Bahasa dan Sastra Indonesia

Volume 13 Nomor 2 Tahun 2018

Tapi mata kami 'kan nyalang bila menonton televisi."

\section{7}

\section{Penutup}

Mewujudkan generasi literat diharapkan

kecakapan/keterampilan tinggi, tapi juga menjadi kesadaran kolektif (guru, dosen, mampu memerankan diri sebagai model sastrawan, penulis buku pelajaran, serta mampu menginspirasi para peserta sekolah, pemerintah, dan masyarakat). didik.Guru harus memiliki hasrat Namun dalam konteks pendidikan, guru atau pendidik memiliki tanggung jawab menggelora untuk melihat para siswa bertumbuh, bermetamorfosis, dan lebih karena gurulah yang berdiri di garda paling depan dalam menyukseskan menyempurna menjadi insan-insan yang pendidikan. Guru diharapkanmenjadi mampu memberdaya dan motor penggerak utama untuk mencetak generasi literat, yakni generasi yang bukan saja memiliki pemahaman atas apa yang dibaca, tapi juga mampu menginternalisasikan nilai-nilai yang terkandung di dalamnya serta mampu mengaktualisasikannya dalam unjuk kerja nyata dan karya-karya prestatif.Generasi literat-generasiyang cerdas, berkompeten, berkarakter, dan berdaya saing - adalah impian yang secara terusmenerus dikhtiarkan untuk dapat diwujudkan.Generasi literat diyakini akan mampu menghasilkan karya-karya besar dan bermakna bagi kemartabatan bangsa. Untuk itu, guru perlu bermetamorfosis dari guru yang biasa menjadi guru yang luar biasa, guru yang bukan saja memiliki mengaktualisasikan dirinya.

\section{DAFTAR PUSTAKA}

Damshäuser, B. 2016.Belajar Dunia kepada Teks, makalah disajika pada Seminar Internasional Riksa Bahasa 10 yang diselenggarakan Universitas Pendidikan Indonesia Bandung, 26 September 2016.

Delgadova, E. 2015. Reading literacy as one of the most significant academic competencies for the university students, ProcediaSocial and Behavioral Sciences 178 ( 2015 ) $48-53$.

Ismail, T. 2008. Mengakar ke Bumi Menggapai ke Langit. Jakarta: Jayakara Agung Offset. 
FON ; Jurnal Pendidikan Bahasa dan Sastra Indonesia

Volume 13 Nomor 2 Tahun 2018

Orlick, T. 2002. Nurturing Positive Living

Skills for Children: Feeding the

Heart and Soul of Humanity

.Journal of Excellence . 7, 86-98.

Peraturan Menteri Penidikan Nasional

Republik Indonesia Nomor 22

Tahun 2006 tentang Standar Isi.

Ravid, D. and Tolchinsky, L. 2002.

Developing linguistic literacy: a comprehensive model, Journal of Child Language 29 (2), pp 417477.

Slavin, R. E. 2008.Psikologi Pendidikan:

Teori dan Praktik, terj. Marianto

Samosir. Jakarta: Indeks.

Suwandi, S.2014. Pembelajaran Bahasa Indonesia Berbasis Teks dengan Pendekatan Saintifik dan Upaya Membangun Budaya Literasi makalah dipresentasikan pada Seminar Nasional yang diselenggarakan Program Studi Pendidikan Bahasa dan Sastra Indonesi FPBS IKIP PGRI Bojonegoro, 7 Juni. . 2015a. "Pendidikan Karakter sebagai Peneretas Jalan Mewujudkan Bangsa Indonesia yang Berjati Diri dan Bermarwah", makalah dipresentasikan dalam Seminar
Nasional Pendidikan yang diselenggarakan STKIP Hamzanwadi Selong, Lombok Timur, Nusa Tenggara Barat, 10 Januari. . 2015b. "Membangun Budaya Literasi untuk Mengembangkan Profesionalisme Guru dan Dosen Bahasa Indonesia", makalah dipresentasikan pada Semnas yang diselenggarakan Asosiasi Dosen Bahasa dan Sastra Indonesia (ADOBSI) bekerja sama dengan Jurusan Pendidikan Bahasa dan Seni FKIP UNS, 25 April.

2016. Pengembangan Budaya Literasi sebagai Investasi Pengukuhan Kemartabatan Bangsa, makalah dipresentasikan dalam Seminar Literasi (Semlit) dengan tema "Mengembangkan Literasi di Indonesia" yang diselenggarakan oleh JurusanBahasa dan Sastra Indonesia Fakultas Bahasa dan Seni Universitas Negeri Surabaya, 29 Oktober 2016.

Wardi, T. D. 2004. Paradigma Baru Literasi, Kompas 23 Novembe. 